\title{
The Political Economy of the SPD Reconsidered: Evidence from the Great Recession
}

\author{
Björn Bremer* \\ European University Institute \\ bjoern.bremer@eui.eu
}

February 2019

Published in German Politics

\begin{abstract}
The transformation of Germany's political economy in the last few decades has strongly been influenced by the SPD. Still, the economic programme of the SPD remains contested since several authors characterise the party's economic platform differently. This paper reconsiders the political economy of the SPD in light of evidence from the Great Recession. It combines quantitative content analysis with process tracing in order to situate the party in research on the moral economy of contemporary Germany. The quantitative content analysis shows that the SPD attempted to shift its position on the welfare state and economic liberalism in response to the crisis, but it remained wedded to orthodox fiscal policies. Based on elite interviews with social democratic politicians and policy-makers, the paper explains this response with the absence of an economic paradigm. Weakened by internal conflict, the SPD made programmatic decisions with reference to electoral calculations and it remained trapped by its pre-crisis support for economic supply-side policies. Therefore, the SPD was unable to oppose the conservative economic discourse in Germany and failed to develop a consistent economic programme in response to the Great Recession.
\end{abstract}

Keywords: Social democratic parties, Great Recession, economic policies, austerity, German politics.

*The author gratefully acknowledges funding from the ERC Project "Political Conflict in Europe in the Shadow of the Great Recession" (Project ID: 338875). I thank Hanspeter Kriesi, Dan Kelemen, Tobias Schulze-Cleven, Sidney Rothstein, Josef Hien, and two anonymous reviewers for very helpful comments and suggestions on this paper. A previous version of this paper was also presented at a workshop for this special issue in San Francisco and I am very grateful for insightful comments from all the other participants. 


\section{Introduction}

In Germany, the Social Democratic Party (SPD) has played a central role in economic policy-making in the last two decades. The party has been a member of the federal government for sixteen out of the last twenty years and it implemented the "Agenda 2010", a set of liberal labour market and welfare state reforms still highly contested in Germany. Consequently, the political economy of the SPD remains equally contested and several scholars characterise the party's economic platform differently (Nachtwey, 2013; Merkel et al., 2008; Seeleib-Kaiser, 2002). This paper reconsiders the political economy of the SPD by using evidence from the Great Recession, which presented the largest economic shock to the advanced economies since the Great Depression. ${ }^{1}$ It exposed the weakness of the existing economic system and challenged much of the conventional wisdom in political economy among policy-makers and academics alike.

This paper therefore has two aims: to analyse how the SPD changed its economic programme in response to the Great Recession and to explain this response. For this purpose, the paper combines quantitative content analysis of election campaigns from before and after the financial crisis with a qualitative case study based on elite interviews with more than 20 social democratic politicians and policy-makers. The quantitative content analysis shows that the SPD attempted to shift its position on the welfare state and economic liberalism, but remained wedded to orthodox fiscal policies in response to the crisis. Thus, the party's programme remains full of inconsistencies, and the paper explains this response by both electoral calculations and the lingering influence of economic ideas that shaped the party's economic programme prior to the Great Recession.

On the one hand, the SPD perceived voters to be fiscally conservative, who expected the government to balance its budget and reduce government debt. The party was concerned with its reputation for economic competence and therefore attempted to gain fiscal credibility by supporting fiscal consolidation (Kraft, 2017). On the other hand, the SPD remained influenced by supply-side economics during the crisis, which had shaped its programme prior to it (also see Bremer and McDaniel, 2019)). Due to the perceived economic success of the Agenda 2010, these ideas were particularly prevalent in Germany and pushed the right wing of the SPD away from traditional Keynesian thinking. At the same time, the Agenda 2010 also caused a political rift as the reforms were very controversial within the party. They undermined the SPD's ties with the trade unions and challenged the party's

\footnotetext{
${ }^{1}$ The Great Recession is defined here as the economic crisis that begun in September 2008, when the US investment bank Lehman Brothers collapsed. It conceptualised both the 2008 financial crisis and the Euro crisis as one economic crisis.
} 
social profile with significant electoral consequences (Schwander and Manow, 2017). Weakened by these internal conflicts, the SPD lacked a clear economic paradigm in the context of the economic crisis and was unable to oppose the prevailing conservative economic discourse, which is still influenced by ordoliberalism (e.g. Blyth, 2013; Young, 2014; Woodruff, 2016) and a moral view on the economy (e.g. SchulzeCleven and Weishaupt, 2015; Hien, 2017; Hien and Joerges, 2017). It embraced an economic programme strongly affected by the perceived public opinion and the economic mainstream, but one that ultimately remained wrought by inconsistencies and contradictions.

To make this argument, the paper proceeds as follows. First, a review of the existing literature provides a short account of the SPD's economic policy since 1945. Second, the paper uses quantitative content analysis to examine the economic programme of the SPD as represented in election campaigns. To this end, the paper utilizes a novel dataset including evidence from eight German elections and builds on earlier research by (Kriesi et al., 2008, 2012). The paper then uses process-tracing to explain the policies that the SPD adopted in the wake of the economic crisis. It draws on insights from 21 elite interviews and complements them with evidence from official documents and public statements by social democrats. Finally, the conclusion summarises the main findings of the analysis and considers the importance of these findings to understand the recent trajectory of social democracy in Germany.

\section{The SPD's Economic Programme before the Great Recession}

Following Peter Hall's concept of "policy paradigms", it is a common premise that parties follow economic paradigms. These paradigms are coherent sets of ideas that serve as prisms through which policy-makers see the economy and their role within it (Hall, 1993, p. 279). However, these ideas are not fixed and instead there is a large amount of ideational change over time (e.g. Hall, 1989; Blyth, 2002). This has also been true for the SPD, which changed its economic policies significantly since 1945. In the beginning of the post-war era, the SPD was still inspired by Marxist ideas that had shaped the party in the previous decades (Berman, 1998). The party remained in favour of interventionist policies (focused on the supply-side) like nationalization, planning, and worker control that opposed the free market (Allen, 1989, p. 273). However, in 1959 the SPD made a programmatic reversal and broke with Marxism, when it adopted the Godesberger programme (e.g. Held, 1982; Przeworski, 1985, p.32). It accepted the basic logic of the free market and embraced a 
Keynesian economic programme similar to that of other European social democratic parties.

The SPD was able to put this programme into practice after it first entered the federal government in the post-war era in 1966. It joined the CDU/CSU in a grand coalition and Karl Schiller, a leading German professor of economics, became finance minister. He responded to the economic crisis of 1966 and 1967 with a large Keynesian stimulus programme. Afterwards, he codified Keynesianism into law by passing the so-called Stabilitäts- und Wachstumsgesetz (Nützenadel, 2005, p. 123ff), which recognized the government's responsibility for maintaining employment and mandated the government to act accordingly. This was the start of a brief Keynesian period in Germany, during which active demand management was used to stabilise the economy. It persisted during the grand coalition (1966-69) and the centre-left government under Willy Brand (1969-1974).

However, Helmut Schmidt, who became the second SPD chancellor in the postwar era in 1974, was more concerned with economic stability than most other social democrats (Scharpf, 1991, p. 131). ${ }^{2}$ In the context of stagflation, he used his first address to the Bundestag as chancellor to 'repel all exaggerated [budget] demands', emphasising that his government would use 'all constitutional and political possibilities to commit the federal, Länder and local governments to a thrifty spending policy from 1975 onwards' (Schmidt, 1974, p.20). Still, Schmidt was pressured by the left wing of his party and the US President Jimmy Carter to stimulate the economy in the late 1970s. The latter wanted Germany to become the economic locomotive for Europe and the rest of the world, and Schmidt partially conceded (Allen, 1989, p. 279). He implemented two large stimulus programmes in 1977 and 1978, but they did not have the desired effect. The autonomy of the central bank as well as pro-cyclical deficit reductions at the state and local level undermined Keynesian demand-management (Scharpf, 1991, p. 239), and eventually Schmidt turned away from deficit spending. He gave in to demands from his coalition partner, the FDP, to implement cuts to consolidate the budget, but in 1982 the coalition nevertheless fell apart.

After 1982, the SPD remained in opposition for sixteen years. The party initially remained wedded to some form of Keynesianism, even if it was more open to supply-side policies than other social democratic parties (Allen, 1989, p. 273). In the late 1980s and the early 1990s the SPD became increasingly divided between the so-called "traditionalists" and the "modernisers", but the party's direction of travel was not entirely clear when the party won the elections in 1998. Instead,

\footnotetext{
${ }^{2}$ Helmut Schmidt still famously said that he would prefer five percent of inflation over five percent of unemployment.
} 
there was a programmatic dualism personified by the chancellor Gerhard Schröder and Oskar Lafontaine, the party leader and finance minister (Nachtwey, 2013, p. 238). This dualism turned into an open conflict, which culminated in the resignation of Lafontaine in March 1999 after he had only served in government for 163 days. Subsequently, the modernisers took control of most levers of government and initiated a reform process.

The new finance minister Hans Eichel was concerned with the sustainability of government debt and implemented fiscal consolidation. Even in the context of Germany's economic crisis in the early 2000s - when Germany was widely called the 'sick man of the Euro' (The Economist, 1999) - Eichel continued to implement a restrictive fiscal policy. ${ }^{3}$ Moreover, Chancellor Schröder attempted to engineer a broader push for reforms. He published a joint paper with Tony Blair, the British Prime Minister and leader of the Labour Party, in which they laid out the rationale for a new economic programme (Blair and Schröder, 1999), often labelled "Third Way" (Giddens, 1998). Although Schröder and Blair stressed that they considered demand- and supply-side policies complementary, the paper is mostly remembered for outlining a new centrist economic strategy for social democratic parties in Europe that focused on supply-side reforms to achieve economic growth. Despite the initial push by the modernisers, the SPD-led government struggled to implement far-reaching reforms based on a corporatist strategy, i.e. an alliance for jobs based on collaboration of the government with representatives of the trade unions and employers. Before the 2002 elections, Schröder created the so-called Hartz commission with the task to develop recommendations for a labour reform. After the red-green government was narrowly re-elected, Schröder intensified the push for reforms and eventually he opted for a post-corporatist strategy (Nachtwey, 2013, p. 240). He announced the Agenda 2010 in March 2003, implementing a set of reforms that liberalised the labour market and the welfare state.

The Agenda 2010 can be seen as a significant re-orientation of Germany's welfare state and it was politically contested (Hassel and Schiller, 2010; Hegelich et al., 2011). Still, there is not one dominant interpretation of the transformation that the SPD underwent at the turn of the century. Seeleib-Kaiser (2002) argues that the SPD converged with the Christian Democratic Union (CDU), while for Merkel et al. (2008) the SPD still stands for a form of "traditional social democracy". In contrast, Nachtwey (2013) argues that the SPD has undergone a process of adaptive self-transformation and now has a distinct model that he calls "market social democracy."

\footnotetext{
${ }^{3}$ Schröder eventually forced Eichel to withdraw from this position (see Figure 4) and Germany was thus the first country (together with France) to break the Maastricht criteria. In 2004 the federal government incurred the largest deficit in the post-war history.
} 


\section{Economic Crisis and the Response of the SPD}

The SPD remained in government until 2009, despite the electoral consequences of the Agenda 2010 (Schwander and Manow, 2017). It lost the election in 2005, but the CDU/CSU and the FDP fell short of a majority. The SPD thus joined a grand coalition under the leadership of Angela Merkel, which governed Germany when the financial crisis hit the advanced economies. After the fall of the American investment bank Lehman Brothers in September 2008, several German banks were at the brink of bankruptcy. Moreover, the financial crisis also led to the deepest recession since the Great Depression and Germany's economy shrank dramatically in 2009 (Figure 1). Although Germany's domestic economy recovered relatively quickly beginning in 2010, the German government remained in crisis mode for several years because the Eurozone crisis kept a tight grip on the Euro.

Figure 1: German real GDP growth, 1991-2015

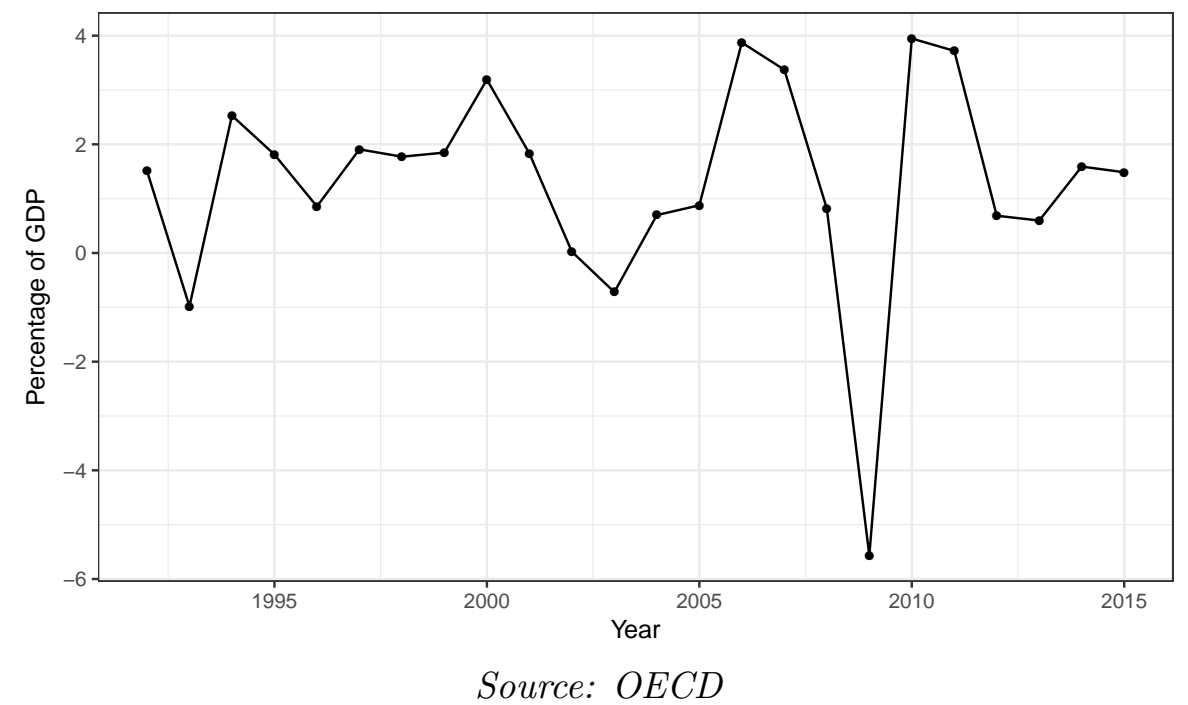

To examine the response of SPD to this economic crisis, I use an original dataset based on quantitative content analysis that allows me to analyse both the positions that parties take on different issues and the salience that they attribute to these issues (see Bremer, 2018). Specifically, the analysis is based on the detailed coding of two newspapers during eight election campaigns. From each newspaper, a representative sample of relevant articles is coded by using core sentence analysis (Kleinnijenhuis and Pennings, 2001; Kleinnijenhuis et al., 1997). The data has been widely used by Kriesi et al. (2012, 2008) and Hutter and Kriesi (2019) to study political competition in Europe in the last few decades. ${ }^{4}$ It enables me to measure the

\footnotetext{
${ }^{4} \mathrm{~A}$ detailed explanation of how the dataset was created is included in Appendix A.
} 
Table 1: List of economic issue categories (adopted from (Kriesi et al., 2008) and (Bremer, 2018))

\begin{tabular}{|c|c|}
\hline Categories & Description of Left-Wing Positions \\
\hline Welfare & $\begin{array}{l}\text { Support for the welfare state and redistribution } \\
\text { through taxes and benefits }\end{array}$ \\
\hline Economic I & $\begin{array}{l}\text { Opposition to competition, deregulation, and pri- } \\
\text { vatization }\end{array}$ \\
\hline Budgetal & $\begin{array}{l}\text { Opposition to a rigid budgetary policy and the re- } \\
\text { duction of taxes (without an explicit redistributive } \\
\text { character) }\end{array}$ \\
\hline
\end{tabular}

position of German parties on different issues over time because it includes data from all elections since 1994 as well as data from the 1976 election as a benchmark.

The advantage of this dataset is that it allows me to classify economic issues into three meta-categories that are concerned with the economy. As shown in Table 1, these three categories are welfare, economic liberalism, and budgetary rigour. ${ }^{5}$ For each category, I calculate two measures as explained in Appendix C. The salience that parties attribute to each issue is simply the share of core sentences that a party devotes to a given issue compared to all other economic issues during the election campaign. The left-right position for a party on a given issue is the average direction of all statements about that particular issue, which ranges from -1 to +1 , where -1 is the left end of the spectrum and +1 is the right end of the spectrum.

Table 2: List of elections by time period

\begin{tabular}{cc}
\hline \hline Time Period & Election \\
\hline $1970 \mathrm{~s}$ & 1976 \\
$1990 \mathrm{~s}$ & 1994,1998 \\
Pre-crisis & 2002,2005 \\
Crisis & 2009,2013 \\
Post-crisis & 2017 \\
\hline \hline
\end{tabular}

To focus on the larger programmatic shifts of the SPD over time, I classify the elections into five different periods, as shown in Table 2. For each period, I first calculate the aggregate left-right position for the SPD and the CDU/CSU. ${ }^{6}$ This allows me to test whether there was a "neoliberal convergence" (Roberts, 2014) prior to the crisis, i.e. whether all the mainstream parties supported market liberalisation. The results are shown in Figure 2. It indicates that in the 1970s, there was a clear difference between the SPD and the CDU/CSU in economic terms, but that

\footnotetext{
${ }^{5} \mathrm{~A}$ list of all issues included in these categories is included in Appendix B.

${ }^{6}$ The left-right position for both parties is calculated by the mean of all statements from the three economic categories, weighted by the salience of the individual categories.
} 
Figure 2: Left-right position of the SPD and CDU/CSU over time

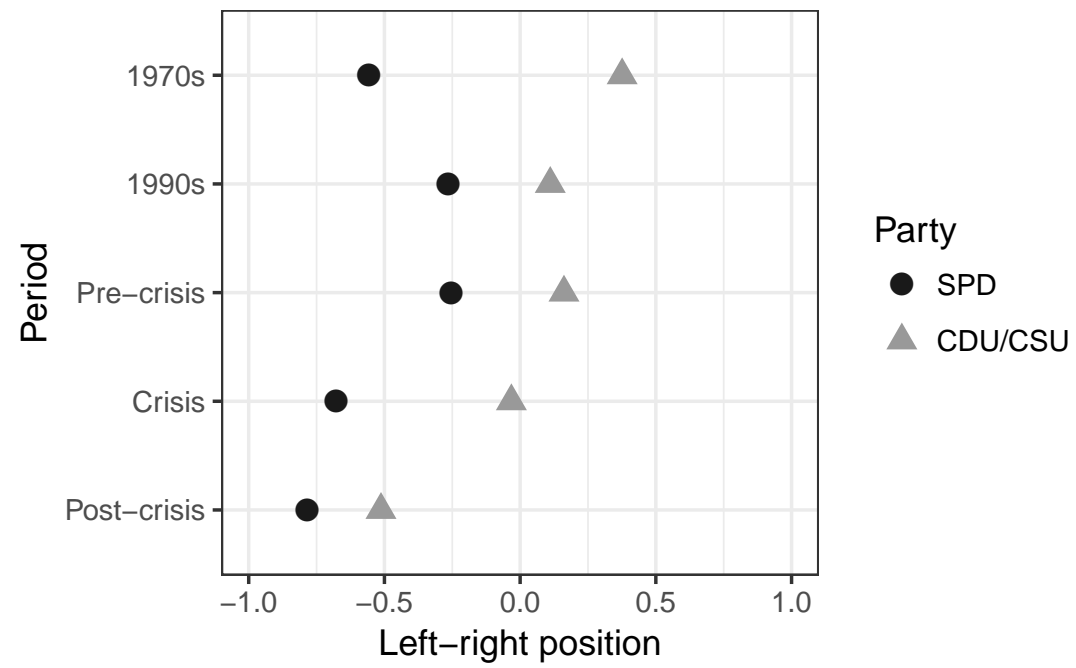

Note: The figure shows the weighted average position of the SPD and the CDU/CSU on all economic issue categories (welfare, economic liberalism, budgetary rigour). The positions are weighted by the relative salience of each category.

this difference became significantly smaller in the 1990s and 2000s. Before the Great Recession, both the SPD and the CDU/CSU had moved towards the centre, which limited the programmatic competition on the economy. ${ }^{7}$ This convergence was partly reversed during the crisis when the SPD markedly moved towards the left, but the left-ward shift of the CDU/CSU under Angela Merkel undermined the SPD's programmatic re-orientation. By adopting very similar positions, the CDU/CSU neutralised much of the SPD's programme (Hutter and Kriesi, 2019). ${ }^{8}$

To properly characterise the economic response of the SPD to the crisis, it is useful to distinguish between the positions of the SPD on the three different economic categories identified above. The results of this exercise are plotted in Figure 3. It shows that in the 1970s, the SPD still had a very consistent economic platform that is in line with traditional left-wing positions. The party supported the welfare state but opposed both economic liberalism and a rigid budgetary policy. In 1976, the pragmatic Schmidt campaigned in the elections with the slogan "Vote for Recovery", but he also proposed to raise revenues by increasing taxes. In the 1990s, the SPD began its march towards the centre by changing its position on bud-

\footnotetext{
${ }^{7}$ For the SPD this move was in the spirit of the Third Way, which Blair and Schröder had outlined in the late 1990s. As discussed above, this Third Way re-oriented social democracy and it culminated in the Agenda 2010 that aimed to reform the German welfare state and labour market.

${ }^{8}$ During the crisis, the SPD also became challenged by electoral competition from the far left after Die Linke was founded as a merger between the east-German Party of Democratic Socialism (PDS) and the Electoral Alternative for Labour and Social Justice (WASG) in 2007.
} 
Figure 3: Left-right position of the SPD for different economic categories over time

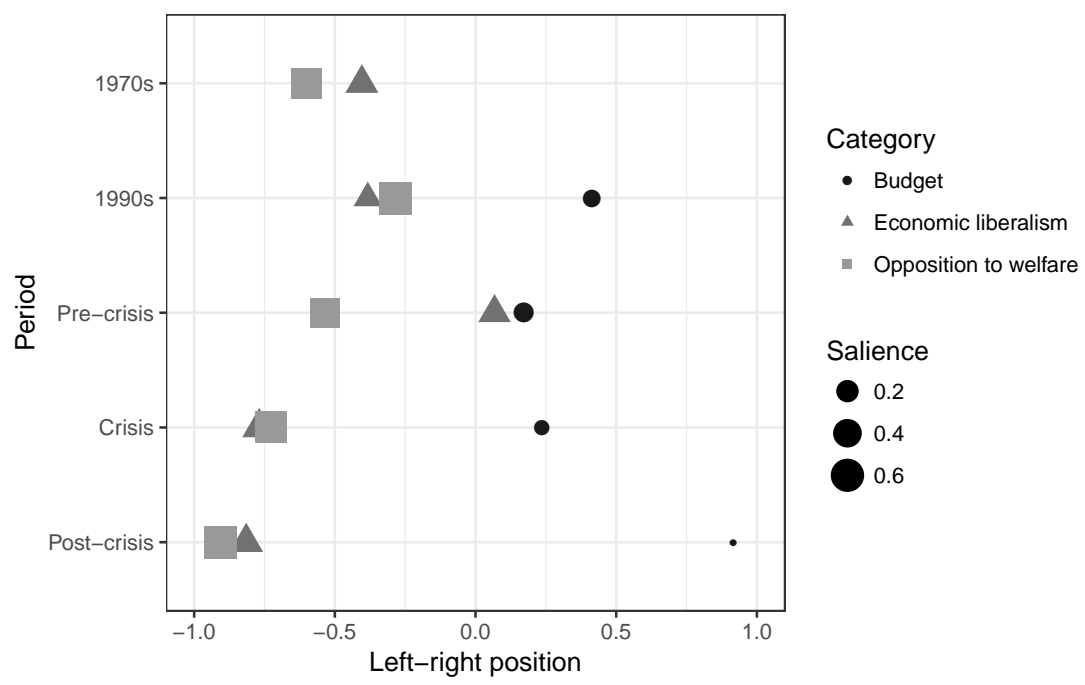

Note: The figure shows the position of the SPD on different economic issue categories. +1 refers to support for budgetary rigour (circle), economic liberalism (triangle), and opposition to welfare (square), respectively. The size of the symbols corresponds to the relative salience of each category.

getary rigour, though. It shifted towards the right and adopted a position that was not much different from the CDU/CSU. In the 2000s, this convergence of the SPD and the CDU/CSU also extended towards economic liberalism. The SPD bought into the dogma of the day and supported a flexibilisation of labour markets and a deregulation of the economy, as set out by the Third Way (Nachtwey, 2013; SeeleibKaiser, 2002). Interestingly, in the early 2000s the SPD hardly changed its position on social policies despite passing the Agenda 2010. The party's commitment to the welfare state thus remained a corner-stone of its electoral programme even though this commitment might not have been credible with the public.

In the wake of the financial crisis, the SPD changed its economic programme yet again. The party shifted towards the left both on welfare and economic liberalism and this shift was particularly large with respect to economic liberalism as social democrats became a lot more sceptical about the merits of free markets. For example, the SPD supported tighter regulation of financial markets and campaigned for the introduction of a minimum wage. At the same time, the party did not change its position on budgetary rigour and still retained a very centrist position during the post-crisis election. Prior to the 2009 election, it had already supported the introduction of the German Schuldenbremse (debt brake) and in the context of the European sovereign debt crisis it retained its commitment to fiscal orthodoxy, i.e. support for balanced budgets and low government debt. This created a significant 
tension within the programme of the SPD: it attempted to campaign on a left-wing platform with regard to social policies and economic liberalism, but it also supported conservative fiscal policies. To deflect from this inconsistency, the SPD increased the salience of issues relating to the welfare state and economic liberalism, while reducing the salience of budgetary policies. This was especially the case in 2017 when the SPD competed on a centrist fiscal programme that hardly featured in the election campaign. Therefore, the party lacked a coherent platform based on an economic paradigm, as defined by (Hall, 1993). Rather, the party combined individual policies from different sides of the economic left-right dimension in a piecemeal fashion, which undermined the SPD's ability to influence the economic discourse in Germany.

\section{Explaining the Response of the SPD to the Economic Crisis}

To explain the puzzling response of the SPD to the Great Recession, I use "explainingoutcome process tracing" (Beach and Pedersen, 2013). Given the results from above, the analysis mostly focuses on the SPD's fiscal policies. It starts with the beginning of the 2008 financial crisis and it ends in 2015 - when the Euro crisis reached its latest climax (with the approval of the third Greek bail-out package) and public attention turned towards the refugee crisis (Hutter and Kriesi, 2019). My main sources are 21 elite interviews with SPD politicians and policy-makers conducted between August 2016 and March 2018, but I complement this evidence with official documents and public statements from leading social democrats. The interviews allow me to unpack the official narrative behind the SPD's economic programme and to elucidate the causal mechanisms behind the party's response to the Great Recession. A full list of all interviews conducted is included in Appendix D, which also explains the rationale for selecting the interviewees. ${ }^{9}$

\subsection{The SPD during the Financial Crisis: Between Stimulus and the Schuldenbremse}

The SPD struggled to develop a coherent position on fiscal policies in response to the Great Recession. Although it was the junior member in the grand coalition, it controlled both the finance and labour ministry when the 2008 financial crisis hit. Originally, Peer Steinbrück had planned to reach a balanced budget by 2011 after

\footnotetext{
${ }^{9}$ All translations of quotations from both interviews and secondary sources are my own.
} 
the centre-left government under Schröder had been widely criticized for breaking the Maastricht criteria in the early 2000s. 'There was a very clear anti-Keynesinian attitude in the finance ministry' (economic advisor, personal interview, 31/01/2018) and several economic advisers reported that Steinbrück was hesitant to mobilise a large amount of financial resources in autumn 2008. He famously said in September 2008 that the financial crisis was an American problem and 'held the position for a long time that Germany did not need to a stimulus package' (economic advisor, personal interview, 31/01/2018). In December 2008, Steinbrück even criticized the stimulus programmes in the UK and elsewhere, saying that 'the switch from decades of supply-side politics all the way to a crass Keynesianism is breathtaking' (Theil, 2008).

Ralf Stegner (personal interview, 19/12/2017), an influential politician from the left of the party and deputy leader of the SPD, argued that in 2008, "the party leadership struggled to shift from the Agenda 2010 towards a demand-driven policy.' As Gustav Horn argued, before the crisis 'the leading paradigm was that Keynesian demand management does not work, which was also the dominant view among the most senior politicians in the SPD' (personal interview, 14/11/2017). Similarly, another economic advisor to the SPD (personal interview, 15/03/2018) emphasised that 'the German view that debt is bad had been dominant within the SPD since the departure of Lafontaine and the party did not have the self-confidence to step out of the shadow and argue against this view.'

However, the view within the finance ministry and the SPD leadership did not go unchallenged. According to Michael Dauderstädt (personal interview, 14/11/2017), 'the SPD was also divided in this situation. The left wing argued very clearly for economic stimulus programmes, but the right wing had reservations about the effectiveness of these programmes.' Still, the voices demanding government action became louder both within and outside the SPD as the crisis worsened. ${ }^{10}$ Eventually, the government agreed on a first stimulus package (Konjunkturpaket I) on 5 November 2008, which was passed by the Bundestag in early December. The package was worth 12 billion Euro and Joachim Poß, responsible for budgetary affairs in the SPD parliamentary group, justified the first stimulus programme by saying that 'we believe that it is right to let the automatic stabilizers of the budget work in the current situation. We believe it is wrong to save in the downturn...We, in the grand coalition, want to actively fight [the crisis]' (Deutscher Bundestag, 2008a, p. 20238).

\footnotetext{
${ }^{10}$ For example, in October 2008, Joachim Poß already argued that 'those who demand spending cuts during the crisis, must not be in their right mind' (Deutscher Bundestag, 2008b, p. 19328).
} 
The first stimulus programme was quickly dismissed as insufficient, though, as it became obvious that the collapse of the world economy would have a large impact on Germany's export-oriented economy. Criticism from unions and employer associations therefore grew louder, who strongly pushed for a different policy (economic advisor, personal interview, 31/01/2017). They called for deficit-spending (Farrell and Quiggin, 2017), and in response to the grim economic outlook at the end of 2008, the SPD took up these calls for more action. It put forward a Pact for Stability and Growth (SPD, 2009) on 4 January 2009, which called for increases in government spending. Among other things, it demanded higher public investment, additional training for the unemployed, a reduction in social security contributions, and cash subsidies for car purchases. The SPD (2009) justified this pact by arguing that

we want to cushion and shorten the imminent crisis with public investments, economic measures and incentives for consumption until the end of 2010. For this purpose, we are prepared to temporarily put aside the goal of balanced state and federal budgets. We act counter-cyclically. Therefore, we believe that it is right and necessary that we pay for the fight against the economic crisis by borrowing more.

Within the span of a few days, the German government largely followed the proposals of the SPD and it agreed on a second stimulus package (Konjunkturpaket II) on 12 January 2009. The package was worth 50 billion Euro and it contributed to a substantial increase in government spending in 2009 and 2010, as shown in Figure 4. Therefore, the SPD eventually also supported fiscal stimulus packages that can be described as "emergency" (Hall, 2013) or "liberal Keynesianism" (Pontusson and Raess, 2012). Although the government was initially more reluctant to pursue Keynesian deficit-spending than some of its European counter-parts (Vail, 2014; Schulze-Cleven and Weishaupt, 2015), it still came a long way in rediscovering the merits of Keynes.

However, the package was not so much influenced by an economic paradigm as by the pressures of the day and the influence of trade unions and employer associations. Poß (personal interview, 22/09/2016) argued that 'in 2008 we had no textbook that we could follow, but there was not much time to develop economic paradigms, either.' Instead, Christian Kellermann (personal interview, 18/12/2017), a former advisor to the SPD's executive board and head of the economic policy unit of the SPD, argued that 'as a result of the pressure, a window of opportunity opened for government stimulus programmes. For a short period of time, this became the new Zeitgeist as it became clear that you had to do something in response to the crisis.' Another economic advisor emphasised that 'in retrospect, Peer Steinbrück realized that he 
had been wrong when all mainstream economists agreed that Germany would need stimulus programmes' (personal interview 15/03/2018).

Figure 4: German government spending and revenues, 1991-2015

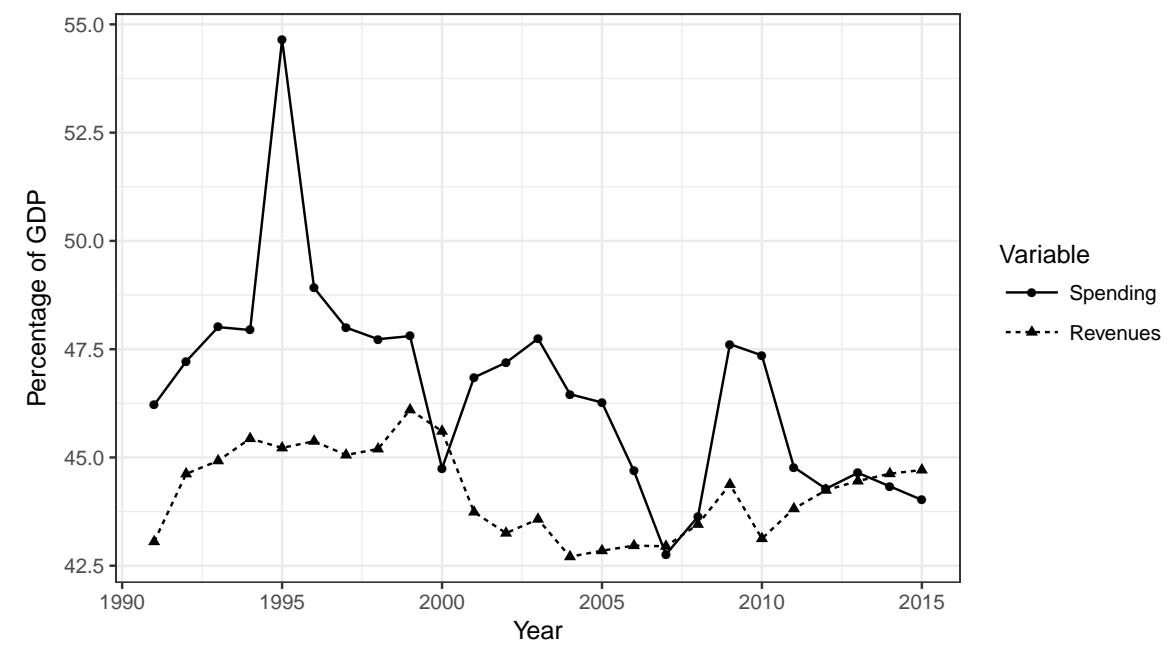

Source: $O E C D$

The stimulus programmes were also supported for electoral reasons. With nine months until elections, the SPD believed that voters expected politicians to have 'courage to take unconditional steps' and to provide 'clear guidance' out of the crisis (SPD, 2009). In this context, the SPD did not only justify additional government spending as demand management pure and simple, but it also emphasised that the additional spending should be used to improve economic productivity. For example, it maintained that the stimulus programmes would 'improve the infrastructure' and 'increase the potential and skills of people' (SPD, 2009). This was in line with the supply-side policies that the party had implemented before the crisis and helped the party to justify its reversal to demand management.

The party's ambiguous position towards Keynesianism also came to light when the grand coalition changed the constitution to include the Schuldenbremse in May 2009. The initiative for this debt brake arose several years before the financial crisis, but calls for such a debt brake grew louder as the government adopted deficit spending. Eventually, both the federal and the state governments agreed to constitutionally limit the size of public deficits: while the federal government would only be allowed to run a deficit up to 0.35 percent of GDP, state governments would be prohibited from running budget deficits at all. ${ }^{11}$ The Schuldenbremse still signalled a clear commitment to fiscal consolidation among German policy-makers, and the

\footnotetext{
${ }^{11}$ In exceptional situations and in order to respond to economic downturns the federal government would still be allowed to run larger government deficits.
} 
SPD was instrumental in ensuring its place in the German constitution. ${ }^{12}$ In the parliamentary debate prior to the vote on the debt brake in March 2009, Steinbrück called the Schuldenbremse a 'decision of historic significance' (Deutscher Bundestag, 2009, p. 24866). He argued that Germany was stuck in a vice of indebtedness and emphasised that fifteen percent of the federal budget had to be used for interest rate payments. This reduced the amount of money that the government could spend otherwise and threatened the capacity of the state in the long-term. Therefore, Steinbrück stressed that 'a state that is able to act needs to have public finances that are viable in the long-term' (Deutscher Bundestag, 2009, p. 24868).

This position was shared among the right wing of the party. Carsten Schneider (personal interview, 22/10/2016), a budgetary spokesperson for the SPD, emphasized that 'higher debt generally also means that the government has to pay higher interest rates. And I do not want us to use government's current income for interest expenses. ${ }^{13}$ Similarly, Johannes Kahrs (personal interview, 16/08/2016), another budgetary spokesperson for the SPD, argued that 'higher debts are a burden on future generations, and it is not fair, from the point of view of generational justice, that we burden future generations with debts that take away all room for manoeuvre.' Even Joachim Poß (personal interview, 22/09/2016) from the left wing of the party argued that 'there are also good reasons that the state gives itself room for manoeuvre. The lower the debt, the higher the ability of the state to act.' This is in line with the "progressive consolidation view" (Haffert and Mehrtens, 2015), which emphasises that consolidation is necessary to ensure the long-term capacity of the state.

Although this view was popular among some SPD politicians, the Schuldenbremse was 'not a SPD project and it was very controversial within the party' (Wolfgang Thierse, personal interview, 07/09/2016). The left wing of the party was concerned that the Schuldenbremse would undermine the fiscal space available to the state and threaten the provision of social services. They were supported by the trade unions (e.g. Deutscher Gewerkschaftsbund, 2009) and by a public appeal from economists spearheaded by Peter Bofinger and Gustav Horn, who argued that 'the restriction of the remaining room for manoeuvre for macroeconomic policies, which the debt brake aims at, endangers the overall economic stability' (Bofinger and Horn, 2009). ${ }^{14}$ As a result, the Schuldenbremse only narrowly passed as nine-teen

\footnotetext{
${ }^{12}$ For example, the debt brake was prepared by the finance ministry, which continuously had been under the control of the SPD since the 1998 election.

${ }^{13}$ Schneider had already been instrumental in putting the question of government debt on the table prior to the economic crisis. He was the author of several papers with other SPD politicians and policy-makers demanding immediate action on Germany's debt.

${ }^{14}$ The appeal was signed by 64 Professors as well as more than 150 other economists.
} 
left wing social democratic MPs voted against the debt brake in the Bundestag and three SPD-led state governments rejected the debt brake in the Bundesrat.

The stimulus packages implemented by the grand coalition had actually made the passage of the Schuldenbremse more likely: against the background of the stimulus, concerns about fiscal sustainability grew larger among voters and politicians. ${ }^{15}$ Consequently, the conflict within the SPD about the Schuldenbremse was decided by tactical reasons. As Stegner (personal interview, 19/12/2017) argued, 'there were only very few people in the SPD that defended the Schuldenbremse on economic grounds. However, the Zeitgeist was extremely powerful, and concerns that we would be portrayed as a debt- and tax-raising party if we were to object to the debt brake dominated the whole debate.' Similarly, Poß (personal interview, 22/09/2016) argued that 'the project was very controversial, but in the political-tactical game we were again and again confronted with the claim from the conservative side that social democrats cannot deal with money. We wanted to counter this claim with the debt brake.' Philipp Steinberg (personal interview, 22/11/2017), then an economic advisor to the SPD leadership, also argued that

we supported the debt brake because we wanted to throw out a certain safety net for ourselves. We wanted to show that we responded to the crisis, but that it is not a general rule that we - as social democrats cannot deal with money...There was some effort to make it clear that the SPD was interested in sound fiscal policies.

The finance minister Peer Steinbrück especially pushed for the debt brake to 're-assure himself that the government's actions were still in line with his pre-crisis policies' (economic advisor, personal interview, 15/03/2018). Yet, the foreign minister Frank-Walter Steinmeier also put his weight behind the initiative. He had already been chosen as the SPD's candidate for the upcoming election in 2009 and it was "very important for him that he was not being seen as the candidate that could not deal with money' (Heiko Geue, personal interview, 21/11/2017). ${ }^{16}$ In the context of the upcoming electoral campaign, the leadership of the SPD was even able to convince many from the left wing of the party. For example, Lothar Binding, the financial spokesperson of the SPD, argued that 'the citizens wanted the debt brake and as a party we could not escape this pressure in 2009. I always tried to

\footnotetext{
${ }^{15}$ Steinbrück explicitly linked the debt brake to the stimulus programmes, arguing that the debt brake was necessary to ensure that the federal and state government would return to the path of fiscal consolidation (Deutscher Bundestag, 2009).

${ }^{16}$ For similar reasons, Steinmeier's economic programme for the elections, the so-called Deutschland Plan, also focused less on the demand-side policies pursued in response to the crisis but more on supply-side policies to generate long-term growth. As one economic advisor put it, the SPD 'never offensively claimed credit for the stimulus programmes...it did not correspond to the German mainstream economic thinking' (economic advisor, personal interview, 15/03/2018).
} 
explain why I did not think it was sound economic policy, but it was not a decision of conscience for me, and thus, I followed the party line in the parliamentary vote' (personal interview, 23/11/2017). As Thierse (personal interview, 07/09/2016) emphasised, the SPD realised that 'to polarise and argue for debt is not popular...the fear of accumulating debt is higher in Germany than it is in other countries.' Ahead of the elections, the SPD was unwilling to argue against this dominant view.

\subsection{The SPD during the Eurozone Crisis: Between Opposition and Government}

In the 2009 elections, the SPD was neither rewarded for the stimulus programmes nor for the debt brake. The party received a devastating 23.0 percent of the votes and was forced to go into opposition. Subsequently, the SPD attempted to renew its economic programme. Sigmar Gabriel, the new party leader, and Frank-Walter Steinmeier initiated an economic council, which was supposed to help develop a new economic profile for the SPD. The council included a very diverse range of advisers, but the push for programmatic renewal was undermined by the Eurozone crisis that began to overshadow day-to-day discussions (Michael Dauderstädt, personal interview, 28/11/2017).

A detailed analysis of the SPD's position on individual bailouts and policies is beyond the scope of this article, but the party struggled to position itself in response to the crisis in the Eurozone. In the beginning of the crisis, the SPD opposed the government's policies and abstained from the vote on the first Greek bailout and the vote on the European Financial Stability Facility in the Bundestag. ${ }^{17}$ However, in autumn 2010 the SPD reverted back into "grand coalition mode" and supported all the other bailouts policies passed in response to the crisis (Degner and Leuffen, 2016, p. 11). Social democrats still tried to condemn the austerity regime created by Angela Merkel and Wolfgang Schäuble, but struggled to consistently challenge the government's approach to the Eurozone crisis. They largely bowed to the German government's view that reckless fiscal spending by debtor countries had caused the Eurozone crisis and that the crisis-ridden periphery needed to implement structural reforms to get out of it.

Privately leading SPD politicians believed that Merkel's strategy was wrong, but they were lost when it came to developing an alternative strategy (Gesine Schwan, personal interview, 11/08/2016). Importantly, the party was confronted with a public debate that was very critical of European transfers and the SPD was very

\footnotetext{
${ }^{17}$ For example, it criticised the government for failing to share the costs of the bailouts with the private sector and made its support conditional on a financial transaction tax (Wonka, 2016).
} 
aware of this sentiment. For example, Johannes Kahrs argued that it was very difficult to explain to voters why Germany should continue to support the Greek government:

When I discuss the issue of Greece in my constituency - whether it's at a house visit, at a public information stand, or even at the Stammtisch - a lot of people say: "you are not serious that you want to again give 50, 60, 70, 80 billion Euro to Greece, are you? We vouch with our own money for this. Are you insane?" (Deutscher Bundestag, 2015a, p. 11383).

This perceived unpopularity of European transfers strongly influenced the SPD. Several politicians confirmed that the SPD leadership believed that public opinion could not be changed, i.e. they regarded themselves as unable to counter the dominant public view that had emerged in Germany. For example, Stegner (personal interview, 19/12/2017) argued that 'to put it bluntly, the SPD was always afraid to debate and propose solutions that had the slightest appearance of leading towards a transfer union. The debates were always conducted aggressively against the SPD, and in this respect the SPD also dreaded the debate and the prevailing opinion.' Similarly, Binding (personal interview, 23/11/2017) argued that 'we did not see an opportunity to change public opinion.' In retrospect, SPD deputy leader Thorsten Schäfer-Gümbel (personal interview, 13/12/2017) argued that 'the SPD was too intimidated during the Euro crisis. Especially with difficult questions, you have to maintain your position, which we did not manage at the time.' Instead, social democrats accepted the dominant narrative about the Eurozone crisis as it was portrayed in the media, and the party leadership chose to run with the majority opinion. ${ }^{18}$

As a result, the party was constantly hedging and repeatedly changed its position. More radical positions that would have challenged the government's policy on the Eurozone were quickly shelved (economic advisor, personal interview, 31/01/2018), and the SPD made its European policy with reference to electoral considerations and national parameters. As Dierk Hirschel (personal interview, 15/12/2017) put it, 'the fear of the Stammtisch was more important than economic arguments.' This was made explicit when Carsten Schneider emphasised that 'we as the German parliament have to make decisions based on the legitimation that we received from our voters. The SPD electoral programme from 2009 did not say that we support direct transfers to other national parliaments' (Deutscher Bundestag, 2015b, p. $7224)$.

\footnotetext{
${ }^{18}$ Dauderstädt (personal interview, 14/11/2017) put this in the following way: 'The party's position was very strongly driven by public opinion...It rather followed the popular Volksseele instead of offensively advocating for other positions.'
} 
Figure 5: German unemployment, 1991-2015

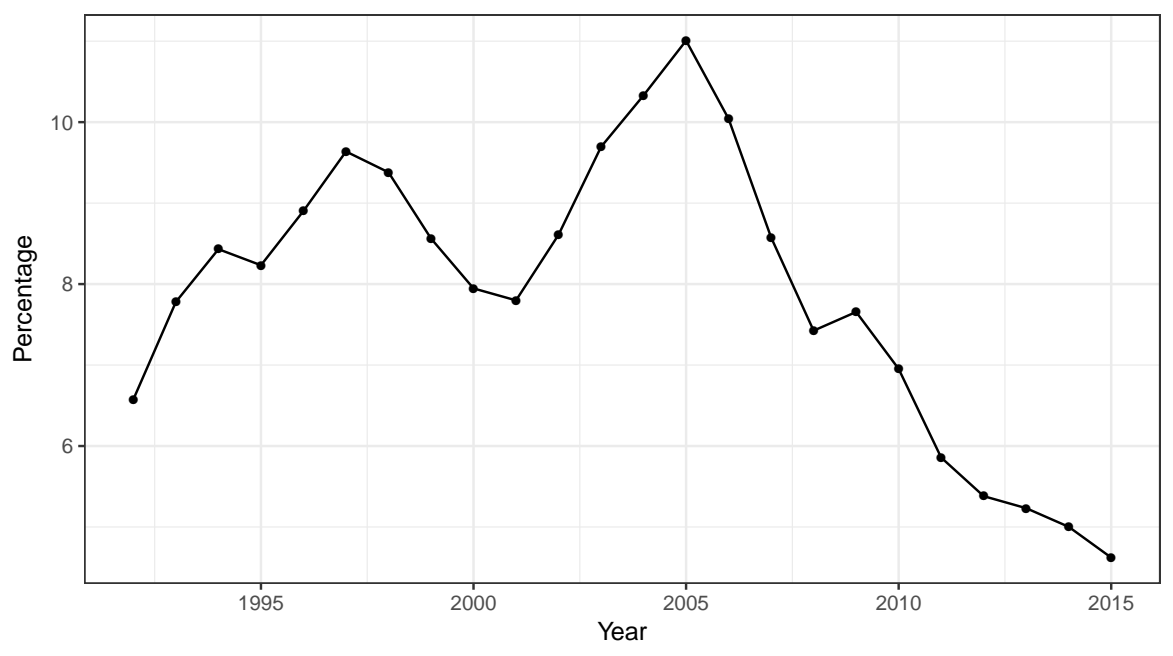

Source: $O E C D$

However, the SPD was not only influenced by electoral considerations, but it was also trapped by its past economic policy. Following the logic of supply-side economics, Germany had undergone painful economic reforms and austerity policies before the crisis. Importantly, during the economic crisis, the Agenda 2010 became increasingly seen as a success-story. While other countries were stuck in the crisis, Germany bounced back relatively quickly and the headline figure of unemployment remained low and continuously declined from 2009 to 2015 (Figure 5). The right wing of the SPD that had supported the Agenda 2010 claimed that this economic situation was the direct result of the reforms, which facilitated the interpretation of the crisis as a morality tale of saints and sinners (Matthijs and McNamara, 2015). As one economic advisor stressed (personal interview, 18/08/2016), 'many people in the SPD who pushed for the Agenda 2010 under Schröder felt compelled to support Merkel's Euro course.' They argued that 'policies that were good for Germany, would also be good for other countries, without considering that austerity might be counter-productive in the middle of the crisis.'

Therefore, the SPD turned towards supply-side economics to justify the lack of European demand-management. Although many politicians were not ideologically convinced by the virtue of austerity, the centrist wing in the party believed that structural reforms were important to solve the crisis and that these reforms would not be pursued if the debtor countries had more fiscal space. According to Schneider (personal interview, 20/10/2016), his experience was that governments would use fiscal space to reduce taxes instead of making productivity-increasing investment. This view was largely in line with the majority of German economists and the 
$\mathrm{CDU} / \mathrm{CSU}$ and therefore the SPD found it difficult to oppose the government's policy. Many SPD politicians, and especially those from the left wing of the party, believed that austerity was the wrong policy (political advisor, personal interview, $19 / 10 / 2017)$, but they were not completely convinced by the virtue of Keynesian demand-stimulus, either.

At the same time, the Euro crisis also had an influence on Germany's domestic economic policy. In Germany, the economy improved in 2010, as shown in Figure 1 above. In the context of the first Greek bail-out, Wolfgang Schäuble argued for fiscal consolidation at home and introduced spending cuts in June 2010. While the trade unions heavily criticised these spending cuts for their redistributive consequences (Vail, 2014), the SPD only put up mild opposition. According to the dominant view in Germany, the crisis illustrated the dangers of too much government debt (Haffert, 2016, p. 27), which strengthened the German suspicion towards public and private debt. ${ }^{19}$ Data from the Eurobarometer, shown in Figure 6, indicates that a large majority of Germans agreed that the reduction of Germany's government debt was a priority throughout the crisis. This pervasive support for fiscal consolidation also influenced the fiscal policies of the SPD. For example, Schäfer-Gümbel (personal interview, 13/12/2018) argued that it was the majority opinion in the leadership of the SPD that you would not survive a mainstream that is clearly against public debt. $^{20}$ In 2011, the SPD agreed to a motion at their party convention, which made the connection between the Euro crisis and domestic policy explicit. It said that 'the crisis in the European Monetary Union shows us with a new urgency that government borrowing needs to be reduced. That is why we will consistently comply with the debt rules and use economic tax revenues to reduce borrowing' (SPD Fraktion, 2011).

The SPD continued to support orthodox fiscal policies when it returned to power in 2013 as a member of the second grand coalition under Merkel. The finance ministry remained in the hands of Schäuble, who presented a balanced budget in the beginning of the legislative period (achieving the so-called Schwarze Null). Despite national and international demands that Germany's government should spend more, the SPD was hesitant to question this policy. Germany's debt-to-GDP ratio still remained above the criteria laid out in the European Stability and Growth Pact (SGP) of 60 per cent and public discourse in Germany was very concerned about lowering

\footnotetext{
${ }^{19}$ This suspicion is, for example, illustrated by the fact that Angela Merkel already referred to the Swabian housewife to whom 'money saved is money earned' in 2009 (Benoit, 2009).

${ }^{20}$ Sigmar Gabriel, who became leader of the SPD in 2009, charted this path. Several politicians and economic advisers described him as a strategic opportunist, who carefully listened to the public mood and opinion polls. Reportedly, he even made his decision to step down as a party leader in January 2017 with reference to opinion polls, which he had commissioned. This style of making decisions was representative for his tenure as party leader from 2009 to 2017.
} 
Figure 6: Attitudes towards government debt in Germany, 2010-2015

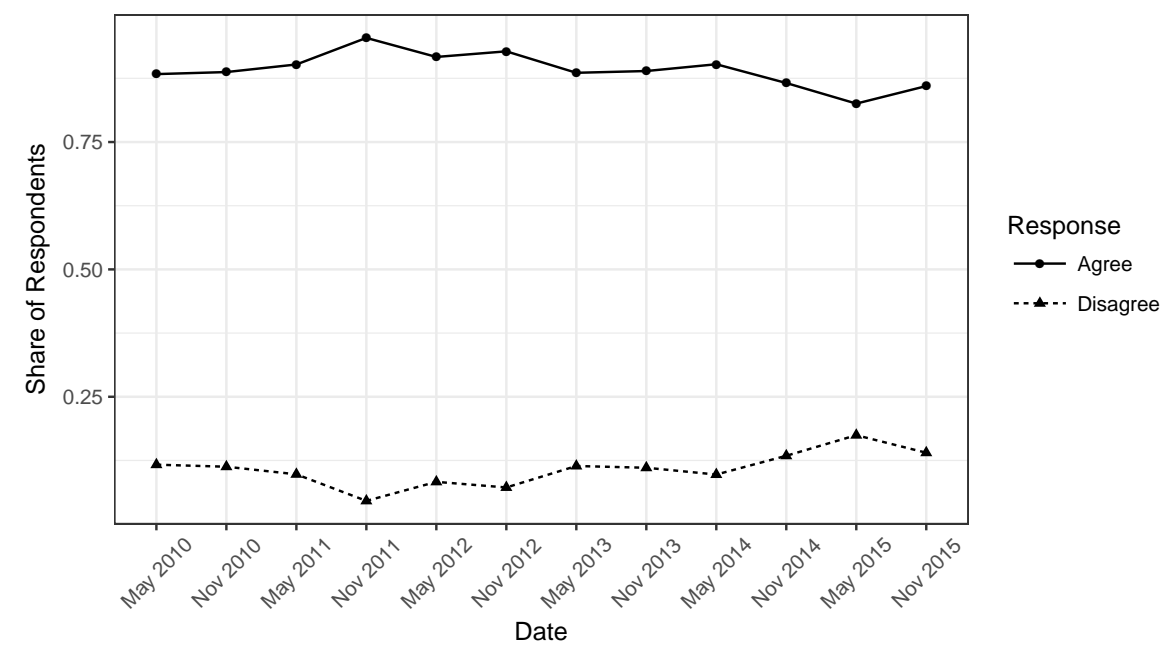

Source: Eurobarometer

Note: The figure shows the share of respondents, who agree or disagree with the statement that 'reducing public debt in Germany cannot be delayed.'

debt. Internally the SPD regularly still had controversial debates, but in public the SPD even presented the Schwarze Null as a success. For example: Kahrs insisted that, 'finally, we are on the way to breaking this dangerous debt spiral...we are reaching a balanced budget... Wir Roten kämpfen für eine schwarze Null' (Deutscher Bundestag, 2014c, p. 2244). Similarly, Thomas Oppermann justified the SPD's support for the balanced budget by arguing that 'only a state that has financial leeway can invest, shape and redistribute' (Deutscher Bundestag, 2014a, p. 4567). Several social democrats emphasised that consolidation was not a fetish, but they returned to arguments about intergenerational justice and the capacity of the state to act in line with the progressive consolidation thesis. This argument was pervasive within the SPD because it allowed the party to legitimise fiscal consolidation on its own terms. In the context of demographic change resulting from an ageing society, the SPD attempted to present fiscal consolidation as an inherently social democratic policy (due to its concern with intergenerational equity).

The Schwarze Null was also supported due to its popularity among voters. In a survey from the Forschungsgruppe Wahlen, 66 percent of the population were in favour of balanced budgets. ${ }^{21}$ Schäuble gleefully cited these survey results in a parliamentary debate saying that 'if you criticise this fiscal policy, you speak

\footnotetext{
${ }^{21} \mathrm{~A}$ summary of the results from the survey is available here: http://www.forschungsgruppe. de/Umfragen/Politbarometer/Archiv/Politbarometer_2014/November_II_2014/ [accessed 20 October 2018].
} 
against the broad conviction of the population as well as the scientific expertise in Germany' (Deutscher Bundestag, 2014b, p. 6420). This was also important for the SPD. Kahrs (personal interview, 16/08/2016) emphasised that "we cannot find a majority in Germany for an alternative policy, not with our coalition partner and not with the prevailing public sentiment in Germany.' Thus the SPD joined the 'competition in which balanced budgets were used as PR strategy to demonstrate economic competence' (political advisor, personal interview, 19/10/2018).

At the same time, the SPD was also aware that Germany's economic positions was threatened by a lack of investments. Before the federal election of 2013, studies by several economic institutes showed that Germany's public and private investments were chronically low compared to other European countries (e.g. Bach et al., 2013). The SPD took up this agenda and in August 2014 Sigmar Gabriel asked Marcel Fratzscher, the President of the German Institute for Economic Research, to chair a commission tasked to address the problem. Still, the SPD remained cautious and did not support large increases in government spending to finance public investments. When it became clear in October 2014 that the economy was growing more slowly than expected, the party did not abandon the aim of balancing the budget - rather social democrats perceived it as a dual challenge to simultaneously balance the budget and increase investments. Some politicians within the party accepted that these aims were partly contradictory, but the party resolved this challenge by arguing that Germany's big problem was the lack of private and not public investments. For example, in 2014 Oppermann said that 'we do not need any debt-financed shortterm flash in the pan programs for the economy, but strategies for more private investments' (Oppermann, 2014). As a result, the SPD only pushed for relatively small increases in public investment and, officially, never questioned the doctrine of balanced budgets. ${ }^{22}$ Rather, it was content to administer the budget surplus jointly with its coalition partner (Rixen, 2018).

Finally, the SPD was also influenced by both public opinion and its historical support for supply-side economics in the discussion about Germany's current account surpluses, which became contested and was widely criticised by other countries in the course of the Eurozone crisis. The left wing of the party was very critical of Germany's surplus (personal interview, economic advisor, 15/03/2018), but the party's leadership took a different position. They did not deny that the current account imbalances in Europe were a problem, but they insisted that reducing them

\footnotetext{
${ }^{22}$ For example, in a joint press release the budgetary spokesmen Schneider and Kahrs emphasised the importance of the balanced budget in 2015 and explicitly argued that 'a balanced budget and higher investments are not a contradiction'. However, in the same press release, they stated that 'with higher public investment, we are securing the maintenance and expansion of the infrastructure and, thus, the future viability of the country' (SPD Fraktion, 2015).
} 
was difficult for the government. Steinberg (personal interview, 22/11/2018) argued that 'reducing current account surpluses is not trivial' and, among other things, he pointed to the limited ability of the government to control wages due to the German Tarifautonomie. Yet. the decision to do little about the current account surpluses was also adopted for political reasons. As one economic advisor (personal interview, $31 / 01 / 2018$ ) put it, 'how can you explain to citizens that an economy can be too competitive and that the current account surpluses can be too high?' The SPD did not have a consistent economic paradigm to answer this question, which prevented the SPD from challenging the European imbalances.

\section{Discussion and Conclusion}

The SPD lacked a clear economic compass in the context of the Great Recession. In response to the deepest economic crisis since the Great Depression, the SPD partly moved away from the Third Way and questioned economic liberalism again. The party did not officially back-track on the Agenda 2010, but it shifted towards the left on social policies and successfully pushed for the introduction of the minimum wage in 2013. At the same time the SPD supported orthodox fiscal policies that undermined its ability to present a coherent economic platform. Although the party implemented emergency policies in the wake of the financial crisis, it did not rediscover Keynes. Instead, it supported the Schuldenbremse and fiscal consolidation at home and abroad during the Eurozone crisis. This created a situation, in which the economic programme of the SPD was often unclear. As Schäfer-Gümbel (personal interview, 13/12/2017) remarked, 'the red threat was not clear enough...we did not have the necessary explanations and we were not brave enough to go into the political dispute and present our positions more clearly.'

Consequently, my analysis suggests that the SPD is a party without a paradigm, which also explains the difficulty of the existing literature to characterise the party's programme. Until this day, the SPD remains internally divided into different factions with different economic ideas: while the left wing remains wedded to a Keynesian understanding of the economy, the right wing of the party is much more influenced by supply-side economics and the German economic mainstream. Lacking a common prism to interpret the world around them, the SPD often reverted to electoral considerations to define its economic positions. The party's support for orthodox fiscal policies was thus largely a defensive reflex: the party believed that it could not withstand the dominant German discourse. As concerns about the public debt grew larger during the economic crisis, the SPD's leaders were worried about their reputa- 
tion for economic competence and they were quick to ascertain fiscally conservative positions.

In the context of the Eurozone crisis, this position became solidified because the SPD found itself in an ideational and discursive trap. After the party had implemented the Agenda 2010 and fiscal consolidation before the financial crisis, Germany's relative economic success prevented the party from disavowing these policies. As a result, people who pushed for a paradigm change inside the SPD were in a difficult situation: trapped by the party's previous economic discourse, SPD leaders often combined electoral opportunism with technocratic policy initiatives. Although many social democrats believed that imposing austerity on the crisisridden periphery was wrong, they were strongly influenced by the dominant German narrative and thus the party was constantly hedging and unwilling to take a clear stance.

In the long-term, this acceptance of fiscal orthodoxy was bad politics, independently of the economics. It contributed to a convergence of mainstream political parties in Germany and undermined the SPD's ability to develop a coherent economic programme. ${ }^{23}$ Almost ten years after the beginning of the financial crisis, this also played a role in the party's defeat in the 2017 elections, when the SPD experienced its worst electoral result in the post-war period. The causes of this defeat are multifaceted, but the inability of voters to differentiate between the SPD and the CDU/CSU was an important factor. Accepting the dominant fiscal and economic framework of the conservative party, the SPD was unwilling to introduce more radical economic policies that could have given it a new profile. Although the party attempted to campaign on a platform that put social justice front and centre, it lacked a coherent narrative that challenged the dominant conservative economic discourse in Germany. As long as the SPD does not break free from this discourse, it will remain trapped by its own triangulation.

\footnotetext{
${ }^{23}$ As shown above in Figure 2, the lack of difference between the SPD and the CDU/CSU also emerged because the CDU/CSU under Angela Merkel strongly moved towards the left. Partly, the CDU/CSU adoptd social democratic positions to demobilise SPD voters.
} 


\section{References}

Allen, C. (1989). The underdevelopment of keynesianism in the federal republic of germany. In P. A. Hall (Ed.), The Political Power of Economic Ideas: Keynesianism Across Nations, pp. 263-289. Princeton, N.J: Princeton University Press.

Bach, S., G. Baldi, K. Bernoth, B. Bremer, B. Farkas, F. Fichtner, M. Fratzscher, and M. Gornig (2013). More growth through higher investment. DIW Economic Bulletin 3(8), 5-16.

Beach, D. and R. B. Pedersen (2013). Process-tracing Methods: Foundations and Guidelines. Ann Arbor, MI: University of Michigan Press.

Benoit, B. (2009). Woman in the news: Angela Merkel. Financial Times, 16 January 2016. Available online at https://www.ft.com/content/ 7a2fb702-e3ed-11dd-8274-0000779fd2ac?o=\%2Frss\%2Fcomment\%2Fanalysis [accessed on 08 August 2017].

Berman, S. (1998). The Social Democratic Moment: Ideas and Politics in the Making of Interwar Europe. Cambridge, Ma: Harvard University Press.

Blair, T. and G. Schröder (1999). Europe: The Third Way/Die Neue Mitte.

Blyth, M. (2002). Great Transformations: Economic Ideas and Institutional Change in the Twentieth Century. Cambridge: Cambridge University Press.

Blyth, M. (2013). Austerity: The history of a dangerous idea. Oxford; New York, NY: Oxford University Press.

Bofinger, P. and G. Horn (2009). Die Schuldenbremse gefährdet die gesamtwirtschaftliche Stabilität und die Zukunft unserer Kinder. Open Letter, 27 May 2009. Available online at https://www.vwl.uni-wuerzburg.de/ fileadmin/12010100/Projekte/Wirtschaftspolitik/Appell_gg_Schuldenbremse_ Stand_27.05.09.pdf [accessed 14 August 2017.

Bremer, B. (2018). The missing left? Economic crisis and the programmatic response of social democratic parties in Europe. Party Politics 24(1), 23-38.

Bremer, B. and S. McDaniel (2019). The ideational foundations of social democratic austerity in the context of the great recession. Socio-Economic Review.

Degner, H. and D. Leuffen (2016). Keynes, Friedman, or Monnet? Explaining parliamentary voting behaviour on fiscal aid for euro area member states. West European Politics 39(6), 1139-1159.

Deutscher Bundestag (2008a). Parliamentary debate, 28 November, 16th Bundestag, Session 188.

Deutscher Bundestag (2008b). Parliamentary debate, 7 October, 16th Bundestag, Session 181.

Deutscher Bundestag (2009). Parliamentary debate, 29 May, 16th Bundestag, Session 225 . 
Deutscher Bundestag (2014a). Parliamentary debate, 10 September, 18th Bundestag, Session 50.

Deutscher Bundestag (2014b). Parliamentary debate, 25 November, 18th Bundestag, Session 68.

Deutscher Bundestag (2014c). Parliamentary debate, 8 April, 18th Bundestag, Session 28 .

Deutscher Bundestag (2015a). Parliamentary debate, 17 July, 18th Bundestag, Session 117 .

Deutscher Bundestag (2015b). Parliamentary debate, 27 February, 18th Bundestag, Session 89.

Deutscher Gewerkschaftsbund (2009). Matecki: Mit schuldenbremse steht ampel für die zukunft auf rot. Press Release, 29 May 2009. Available online at http://www.dgb.de/presse/++co++fcd453de-1560-11df-4ca9-00093d10fae2? tab $=$ Pressemeldung\&display_page $=6 \&$ search_text $=$ schuldenbremse\&end date $=2999-12-31 \&$ start_date=1900-01-01f [accessed 14 August 2017].

Farrell, H. and J. Quiggin (2017). Consensus, Dissensus, and Economic Ideas: Economic Crisis and the Rise and Fall of Keynesianism. International Studies Quarterly 61(2), 269-283.

Giddens, A. (1998). The Third Way: The Renewal of Social Democracy. Malden, Mass: Polity Press.

Haffert, L. (2016). Die schwarze Null: Über die Schattenseiten ausgeglichener Haushalte. Suhrkamp Verlag.

Haffert, L. and P. Mehrtens (2015). From austerity to expansion? Consolidation, budget surpluses, and the decline of fiscal capacity. Politics 83 Society 43(1), 119-148.

Hall, P. (2013). The political origins of our economic discontents: Contemporary adjustment problems in historical perspective. In M. Kahler and D. A. Lake (Eds.), Politics in the New Hard Times: The Great Recession in Comparative Perspective, pp. 129-149. Ithaca, NY: Cornell University Press.

Hall, P. A. (Ed.) (1989). The Political Power of Economic Ideas: Keynesianism Across Nations. Princeton, N.J: Princeton University Press.

Hall, P. A. (1993). Policy paradigms, social learning, and the state: The case of economic policymaking in Britain. Comparative Politics 25(3), 275-296.

Hassel, A. and C. Schiller (2010). Der Fall Hartz IV: Wie es zur Agenda 2010 kam und wie es weitergeht. Frankfurt am Main: Campus Verlag.

Hegelich, S., D. Knollmann, and J. Kuhlmann (2011). Agenda 2010: Strategien Entscheidungen - Konsequenzen. Berlin: Springer-Verlag.

Helbling, M. and A. Tresch (2011). Measuring party positions and issue salience from media coverage: Discussing and cross-validating new indicators. Electoral Studies 30(1), 174-183. 
Held, M. (1982). Sozialdemokratie und Keynesianismus: Von der Weltwirtschaftskrise bis zum Godesberger Programm. Frankfurt am Main: Campus Verlag.

Hien, J. (2017). The religious foundations of the european crisis. JCMS: Journal of Common Market Studies, Online first.

Hien, J. and C. Joerges (Eds.) (2017). Ordoliberalism, law and the rule of economics. Oxford; Portland: Bloomsbury Publishing.

Hutter, S. and H. Kriesi (Eds.) (2019). European Party Politics in Times of Crisis. Cambridge: Cambridge University Press.

Kleinnijenhuis, J., J. A. de Ridder, and E. M. Rietberg (1997). Reasoning in economic discourse: An application of the network approach to the Dutch press. In C. Roberts (Ed.), Text Analysis for the Social Sciences: Methods for Drawing Statistical Inferences from Texts and Transcripts. Mahwah: Erlbaum, pp. 191-207. Erlbaum.

Kleinnijenhuis, J. and P. Pennings (2001). Measurment of party positions on the basis of party programmes, media coverage and voter perceptions. In M. Laver (Ed.), Estimating the Policy Position of Political Actors, pp. 162-182. London: Routledge.

Kraft, J. (2017). Social democratic austerity: The conditional role of agenda dynamics and issue ownership. Journal of European Public Policy 24(10), 1430-1449.

Kriesi, H., E. Grande, M. Dolezal, M. Helbling, D. Höglinger, S. Hutter, and B. Wüest (2012). Political Conflict in Western Europe. Cambridge: Cambridge University Press.

Kriesi, H., E. Grande, R. Lachat, M. Dolezal, S. Bornschier, and T. Frey (2008). West European Politics in the Age of Globalization. Cambridge: Cambridge University Press.

Matthijs, M. and K. McNamara (2015). The euro crisis' theory effect: Northern saints, southern sinners, and the demise of the eurobond. Journal of European Integration 37(2), 229-245.

Merkel, W., A. Petring, C. Henkes, and C. Egle (2008). Social Democracy in Power: The Capacity to Reform. Abingdon-on-Thames: Routledge.

Nachtwey, O. (2013). Market social democracy: The transformation of the SPD up to 2007. German Politics 22(3), 235-252.

Nützenadel, A. (2005). Stunde der Ökonomen: Wissenschaft, Politik und Expertenkultur in der Bundesrepublik 1949-1974. Göttingen: Vandenhoeck \& Ruprecht.

Oppermann, T. (2014). Pressestatement. 14 October 2014. Available online at http: //www.spdfraktion.de/presse/videos/wir-halten-ausgeglichenen-haushalt-fest [accessed 9 August 2017]. 
Pontusson, J. and D. Raess (2012). How (and Why) Is This Time Different? The Politics of Economic Crisis in Western Europe and the United States. Annual Review of Political Science 15, 13-33.

Przeworski, A. (1985). Capitalism and Social Democracy. Cambridge; New York, NY: Cambridge University Press.

Rixen, T. (2018). Administering the surplus: The grand coalition's fiscal policy, 2013-17. German Politics.

Roberts, K. M. (2014). Changing Course in Latin America: Party Systems in the Neoliberal Era. New Yor, NY: Cambridge University Press.

Scharpf, F. W. (1991). Crisis and Choice in European Social Democracy. Ithaca: Cornell University Press.

Schmidt, H. (1974). Regierungserklärung vom 17. Mai 1974.

Schulze-Cleven, T. and J. T. Weishaupt (2015). Playing Normative Legacies: Partisanship and Employment Policies in Crisis-Ridden Europe. Politics \& Society 43(2), 269-299.

Schwander, H. and P. Manow (2017). 'Modernize and die'? German social democracy and the electoral consequences of the agenda 2010. Socio-Economic Review 15(1), 117-134.

Seeleib-Kaiser, M. (2002). Neubeginn oder Ende der Sozialdemokratie? Politische Vierteljahresschrift 43(3), 478-496.

SPD (2009). Pakt für Wachstum und Stabilität. 5 January 2009.

SPD Fraktion (2011). Stabilität der Eurozone sichern. 13 July 2011. Available online at http://www.spdfraktion.de/themen/stabilitaet-eurozone-sichern [accessed on 8 August 2017.

SPD Fraktion (2015). SPD setzt höhere Investitionen in der Finanzplanung durch. 3 March 2015. Available online at http://www.spdfraktion.de/presse/ pressemitteilungen/spd-setzt-hoehere-investitionen-finanzplanung [accessed on 8 August 2017].

Stokes, D. E. (1963). Spatial models of party competition. The American Political Science Review 57(2), 368-377.

The Economist (1999). The sick man of the euro. 3 June 1999. Available online at ttps://www.economist.com/node/209559 [accessed on 8 August 2017].

Theil, S. (2008). Peer Steinbrück on the Global Economic Crisis. Newsweek, 5 December 2008. Available online at http://www.newsweek.com/ peer-steinbruck-global-economic-crisis- 83363 [accessed on 8 August 2017].

Vail, M. I. (2014). Varieties of liberalism: Keynesian responses to the Great Recession in France and Germany. Governance 27(1), 63-85.

Wonka, A. (2016). The party politics of the Euro crisis in the German Bundestag: frames, positions and salience. West European Politics 39(1), 125-144. 
Woodruff, D. M. (2016). Governing by panic the politics of the Eurozone crisis. Politics 85 Society $44(1), 81-116$.

Young, B. (2014). German ordoliberalism as agenda setter for the euro crisis: Myth trumps reality. Journal of Contemporary European Studies 22(3), 276-287. 


\section{Online Appendix}

\section{A Data Collection}

The data was collected as part of the XXX project at XXX. For each election, we selected all newspaper articles that were published within two months before the national election day and reported on the electoral contest as well as national party politics more generally. Editorials and commentaries were excluded and the selection of articles was done by an extensive keyword list including the names and abbreviations of political parties and key politicians from each party. We then coded a sample of the selected articles using core sentence analysis (CSA). Following this type of relational content analysis, each grammatical sentence of an article is reduced to its most basic 'core sentences' structure, which contains only a subject, an object, and the direction of the relationship between the two. The core sentence approach was developed by Kleinnijenhuis et al. (1997) and Kleinnijenhuis and Pennings (2001) and later extensively used by Kriesi et al. (2008) and Kriesi et al. (2012). This type of quantitative content analysis allows us to study both the salience that parties attribute to certain issues and the positions that they take towards these issues. For this purpose, we quantify the direction between actors and issues by using a scale ranging from -1 to +1 , with three intermediary positions $-0.5,0$, and +0.5 . For example, the grammatical sentence "Party A calls for leaving the Eurozone but supports a haircut on the country's debt" leads to two coded observations: (Party A -1 Eurozone; Party A +1 haircut).

Table 3: List of vague issues included in the data

\begin{tabular}{ll}
\hline \hline \multicolumn{1}{c}{ Category } & \multicolumn{1}{c}{ Issue } \\
\hline Welfare & Reduction of unemployment \\
Welfare & Reduction of youth unemployment \\
Economic liberalism & Support small and medium enterprises \\
Economic liberalism & Export oriented measures \\
Economic liberalism & Measures to promote innovation \\
Economic liberalism & Promotion of national business \\
Budgetary rigour & Measures to fight economic crisis \\
\hline \hline
\end{tabular}

Therefore, the coding procedure is, in principle, relatively simple. However, there are also some difficult decisions that one has to make when coding articles. For example, it is often difficult to disentangle whether a sentence includes clear partisan statements that can be used to extract a direction between an actor and an issue or another actor. In general, we always tried to code as many sentences as possible including vague ones. Consequently, our list of issues also includes statements that 
could be considered valence issues, as defined by (Stokes, 1963). For example, a list of such issues with regard to the economy is shown in table 3. Generally, most actors agree on these issues and, hence, they do not help to classify parties based on their (relative) positions. Still, I keep all observations on these issues in the dataset in order to study salience. The only observations that are excluded from the analysis in this paper are actor-actor sentences without an issue reference. They neither include information about salience nor positions. Technically, actor-actor sentences with an issue reference are also not included in the analysis. However, during the coding procedure we always automatically coded all actor-issue sentences that derived from actor-actor sentences with an issue-reference (as shown above) and, hence, my analysis still captures the importance of these sentences for salience.

For the coding of the German elections we used one tabloid and one broadsheet newspapers. Specifically, we coded articles from the Süddeutsche Zeitung and Bild. To create the dataset, we coded the function, party affiliation, and (if available) name of actors, but for the present analysis the actors were grouped according to their party family. The issues, in turn, were coded inductively, i.e. coders were given a long list of possible issues but they were encouraged to add to this list during the coding procedure. This resulted in more than 200 coded issues per election campaign and, as described in the main text, the issues were then aggregated into three economic categories prior to the analysis. Note that each category that I identified includes several different issues, as listed in B.These issues, in turn, often contain several sub-issues that were coded inductively. For example, the issue 'budgetary rigour' contains the following sub-issues: 'budgetary rigour (in general)', 'austerity measures', 'fighting deficit', and retrenchment'. Note that I decided to split issues relating to taxation into two different categories: taxes with an explicit redistributive character (e.g. wealth tax, tax on top-income levels, etc.) were coded as redistribution (i.e. welfare), whereas all other statements about taxation that were more general were coded as budgetary issues.

The major benefit of using an inductive coding procedure is that it allows one to study the full complexity of political competition by coding all statements in the media irrespective of pre-developed categories. Still, there are some disadvantages of studying political competition in this way. First, the major disadvantage is that the data collection is very work intensive because it relies on manual coding. Coder disagreement is potentially also a problem but based on the experience of previous rounds of data collection, we attempted to reduce coder disagreement. For this purpose, we relied on refined coding instruction, trained all coders intensively and continuously monitored their progress. Moreover, each electoral campaign in a given country was coded by at least two coders to reduce individual biases. A third 
potential problem for our data is that it relies on the media to represent the positions of parties. Given that there is some variation in the way that different newspapers report on political competition this might introduce some biases. As a result, in some instances the representation of parties varies across newspapers, but these variations are generally small and not systematic. Moreover, using other data to check the robustness of our findings shows that by and large our coding procedure leads to positions that are similar to those recorded in other datasets (also see Helbling and Tresch, 2011). 


\section{B List of Issues by Category}

Table 4: List of issues by category (adopted from Kriesi et al. 2008)

\begin{tabular}{ll}
\hline \multicolumn{1}{c}{ Category } & \\
\hline \hline Welfare & Welfare (general) \\
& Redistribution \\
& Health care \\
& Retirement \\
& Unemployment \\
& Poverty \\
& Families \\
& Disability support \\
& Consumer rights \\
\hline Economic liberalism & Economic liberalism (general) \\
& Housing market \\
& Labour market \\
& Free trade \\
& Agriculture \\
& Finance \\
& Enterprise \\
& Competition \\
& Market regulation \\
& Keynesianism \\
Corporatism & Promotion of business \\
& Budgetary rigour (general) \\
& Austerity \\
Indirect taxation \\
Direct taxation \\
\hline \hline
\end{tabular}




\section{Methods}

To study the salience that parties attribute to certain issues and the positions that parties take towards these issues, I calculate two key measures from the data. First, salience is measured by the share of core sentences coded for a party on a given issue category compared to all the sentences coded for that party. For example, if there are 10 core sentences for party $\mathrm{A}$ and three of these core sentences are about welfare policies, then the salience of welfare for party A is $3 / 10=0.3$. Second, I calculate the left-right position for a party as the average direction of all statements on an issue category, which ranges from -1 to +1 where -1 is the left end of the spectrum and +1 is the right end of the spectrum. For example, if party $\mathrm{A}$ has two positive statements $(+1)$ and one negative statement $(-1)$ towards welfare, the average position of party A towards welfare is $1+1+(-1) / 3=0.33$. Using these simple rules, I get a dataset with the salience and the positions for each party on each category for every election.

I also use these measures to calculate the salience and left-right position for every party on the aggregate level, i.e. for all economic issues. The salience of all economic issues for a party $k$ is simply the sum of party-specific salience of all the three issue categories:

$$
\text { Aggregate } \text { Salience }_{k}=s_{\text {welfare }, k}+s_{\text {ecolib }, k}+s_{\text {budget }, k}
$$

where $s_{\text {welfare, }}$ is the number of core sentences for party $k$ about welfare while $s_{\text {ecolib }, k}$ and $s_{\text {budget }, k}$ are the number of core sentences for party $k$ about liberalism and budgetary rigour, respectively. The aggregate left-right position for any given party $k$ is calculated as the mean of all statements from the three economic categories, weighted by the salience of the individual categories. It is computed as follows:

$$
\begin{array}{r}
\text { Aggregate Left }- \text { Right Position } k \\
= \\
\frac{s_{\text {welfare }, k} * \bar{x}_{\text {welfare }, k}-s_{\text {ecolib }, k} * \bar{x}_{\text {ecolib }, k}-s_{\text {budget }, k} * \bar{x}_{\text {budget }, k}}{s_{\text {welfare }, k}+s_{\text {ecolib }, k}+s_{\text {budget }, k}}
\end{array}
$$

where $\bar{x}_{\text {welfare }, k}$ is the average position of party $k$ on welfare while $\bar{x}_{e c o l i b, k}$ and $\bar{x}_{b u d g e t, k}$ are the average positions of party $k$ on economic liberalism and budgetary rigour, respectively. 


\section{List of Interviews Conducted}

I selected my interview partners by combining a 'purposive sampling method with a 'chain' or 'snowballing' sampling method. I first tried to identify the key politicians and policy-makers that influenced the response of the SPD to the Great Recession. Second, I encouraged my initial respondents to suggest other people, who are relevant to answer my research question (Biernacki and Waldord, 1981; Farquarharson, 2005). In this way, I tried to identify influential players, who are not obvious ex ante. Based on this reasoning, I conducted interviews with the following 21 policy-makers between August 2016 and March 2018:

- Anonymous, Advisor to the SPD parliamentary group in the Bundestag

- Lothar Bindig, MP and spokesperson for financial affairs of the SPD parliamentary faction

- Michael Dauderstädt, former head of the Economic and Social Policy department of the Friedrich-Ebert-Stiftung

- Sebastian Dullien, Professor of Macroeconomics at the HTW Berlin University and economic advisor to the SPD

- Henrik Enderlein, Professor of Political Economy at the Hertie School of Governance and economic advisor to the SPD

- Andrä Gärber, head of the Economic and Social Policy department of the Friedrich-Ebert-Stiftung

- Heiko Geue, former head of Political Staff at the Federal Ministry of Finance

- Björn Hacker, Professor at the HTW Berlin University of Applied Sciences and Former analyst at the Friedrich Ebert- Stiftung, Berlin

- Dierk Hirschel, Chief Economist at ver.di United Services Trade Union and member of the Commission for Fundamental Values of the SPD

- Gustav Horn, Academic Director of the Macroeconomic Policy Institute (IMK)7

- Johannes Kahrs, MP and budgetary spokesperson of the SPD parliamentary group

- Christian Kellermann, former advisor to SPD's executive board and head of economic policy unit

- Joachim Poß, Former MP and deputy chairman of the SPD parliamentary group responsible for economic affairs 
- Carsten Schneider, MP and First Secretary of the SPD parliamentary group, former Deputy Chairman of the SPD parliamentary group responsible for economic affairs

- Gesine Schwan, head of the Commission for Fundamental Values of the SPD

- Philipp Steinberg, Director-General for Economic Affairs at the Federal Ministry of Economic Affairs and Energy and former senior advisor to SPD Chairman Sigmar Gabriel

- Gerald Steininger, senior advisor on financial affairs of the SPD parliamentary group

- Ralf Stegner, deputy leader of the SPD

- Thorsten Schäfer-Gümbel, deputy leader of the SPD

- Kerstin Villalobos, senior advisor on European politics of the SPD parliamentary group

- Wolfgang Thierse, former President of the Bundestag and deputy chairman of the SPD 